\title{
Mutagenicity and antimutagenicity of (-)-hinokinin a trypanosomicidal compound measured by Salmonella microsome and comet assays
}

Flávia Aparecida Resende ${ }^{1 *}$, Lilian Cristina Barbosa², Denise Crispim Tavares², Mariana Santoro de Camargo ${ }^{2}$, Karen Cristina de Souza Rezende ${ }^{2}$, Márcio Luis de Andrade e Silva ${ }^{2}$ and Eliana Aparecida Varanda ${ }^{1}$

\begin{abstract}
Background: The dibenzylbutyrolactone lignan (-)-hinokinin (HK) was derived by partial synthesis from (-)-cubebin, isolated from the dry seeds of the pepper, Piper cubeba. Considering the good trypanosomicidal activity of $\mathrm{HK}$ and recalling that natural products are promising starting points for the discovery of novel potentially therapeutic agents, the aim of the present study was to investigate the (anti) mutagenic/genotoxic activities of HK.

Methods: The mutagenic/genotoxic activities were evaluated by the Ames test on Salmonella typhimurium strains TA98, TA97a, TA100 and TA102, and the comet assay, so as to assess the safe use of HK in the treatment of Chagas' disease. The antimutagenic /antigenotoxic potential of HK were also tested against the mutagenicity of a variety of direct and indirect acting mutagens, such as 4- nitro-o-phenylenediamine (NOPD), sodium azide (SA), mitomycin $C$ $(\mathrm{MMC})$, benzo[a]pyrene $(\mathrm{B}[a] \mathrm{P})$, aflatoxin $\mathrm{B}_{1}\left(\mathrm{AFB}_{1}\right)$, 2-aminoanthracene (2-AA) and 2-aminofluorene (2-AF), by the Ames test, and doxorubicin (DXR) by the comet assay.

Results: The mutagenicity/genotoxicity tests showed that HK did not induce any increase in the number of revertants or extent of DNA damage, demonstrating the absence of mutagenic and genotoxic activities. On the other hand, the results on the antimutagenic potential of HK showed a strong inhibitory effect against some direct and indirect-acting mutagens.

Conclusions: Regarding the use of HK as an antichagasic drug, the absence of mutagenic effects in animal cell and bacterial systems is encouraging. In addition, HK may be a new potential antigenotoxic / antimutagenic agent from natural sources. However, the protective activity of HK is not general and varies with the type of DNA damage-inducing agent used.
\end{abstract}

Keywords: Hinokinin, Ames test, Comet assay, Mutagenicity, Antimutagenicity

\section{Background}

(-)-Hinokinin (HK - Figure 1), a dibenzylbutyrolactone lignan, was derived by partial synthesis from $(-)$-cubebin (Figure 1) isolated from the dry seeds of Piper cubeba [1] and proved to be a potential candidate for the development of a new drug to treat Chagas' disease $[2,3]$. The

\footnotetext{
* Correspondence: flaviabiomed@yahoo.com.br

'Departamento de Ciências Biológicas, UNESP-Universidade Estadual Paulista Julio de Mesquita Filho- Faculdade de Ciências Farmacêuticas de Araraquara, Araraquara, São Paulo 14801-902, Brazil

Full list of author information is available at the end of the article
}

drugs currently used to treat Chagas' disease are two nitroheterocyclic drugs, the nitrofuran nifurtimox $\left(\mathrm{Lampit}^{\circledR}\right)$, whose production has now been discontinued, and the 2-nitroimidazole benznidazole (Rochagan ${ }^{\circledR}$ ) [4]. These drugs have demonstrated several limitations in use, in part due to their low bioavailability, their limited efficacy against the various stages of the disease and the development of parasite resistance. The other main contraindication of both drugs is their significant toxicity [5].

The most frequent side effects of these drugs include anorexia, vomiting, peripheral polyneuropathy and allergic 

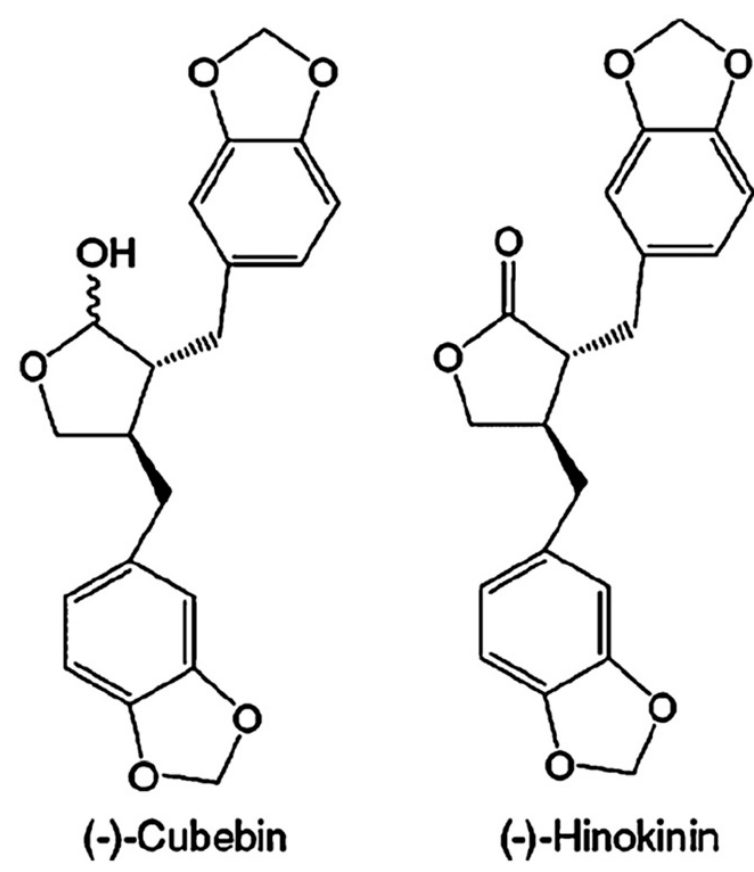

Figure 1 Chemical structures of (-)-cubebin and (-)-hinokinin.

dermopathy. In vivo toxic effects and mutagenicity have been clearly proved in the case of nifurtimox [6]. Also, benznidazole has exhibited genotoxic effects in vitro [7] and significant in vivo alterations [8]. For this reason, the development of safer and more effective drugs for Chagas' disease is an urgent priority [5].

Studies have shown that HK has higher trypanosomicidal activity than benznidazole against epimastigote forms and a similar activity against amastigote forms [2,9], which aroused considerable scientific interest in this lignan. Moreover, HK exhibits activity against oral pathogens, including Streptococcus mutans [10], antioxidant activity in vitro [1], analgesic and anti-inflammatory activities [11], as well as antimutagenic activity by the micronucleus test, in vivo [1] and in vitro [12].

In light of the good trypanosomicidal activity of HK and given that natural products are promising sources of novel potentially therapeutic agents, the aim of the present study was to investigate its mutagenic and genotoxic activities by the Ames and comet assays, respectively, to assess the safety of using HK in the treatment of Chagas' disease. In the absence of such activity, the antimutagenic and antigenotoxic potential would also be tested, with a view to discovering antiparasite agents that can protect the genetic material against damage.

\section{Methods}

\section{Isolation of (-)-cubebin}

Powdered seeds from commercially available Piper cubeba L. fruits were exhaustively extracted by maceration with
$96 \%$ ethanol. The crude extract was concentrated by evaporation and partitioned between hexane and methanol/ water (9:1) phases, providing $430 \mathrm{~g}$ of the dried methanol/ water fraction. This mass was submitted to repeated column chromatography on $1.0 \mathrm{~kg}$ silica gel $(12 \times 120 \mathrm{~cm})$. The cubebin-rich fractions (hexane/dichloromethane 1:1 and $100 \%$ dichloromethane) were subjected to repeated crystallization in hexane/acetone to provide crystalline (-)-cubebin $(37 \mathrm{~g}), \mathrm{mp} 130-131^{\circ} \mathrm{C},[\alpha]_{D}^{26}-8.12^{\circ}$ (c 0.46 , $\mathrm{CHCl}_{3}$ ). The chemical structure was confirmed by ${ }^{1} \mathrm{H}$ NMR and IR, by comparison with published data [13]. Purity was estimated to be $99 \%$ by both HPLC and spectral data analysis.

\section{Preparation of (-)-hinokinin}

(-)-Cubebin (0.5004 $\mathrm{g}$ in $10 \mathrm{~mL}$ dichloromethane) was treated with two equivalents $(2.32 \mathrm{mM})$ of pyridinium chlorochromate at room temperature and the reaction mixture was stirred for $12 \mathrm{~h}$. The solvent was removed under vacuum and the residue was submitted to chromatography on silica gel, eluted with hexane-ethyl acetate (4:1), yielding $0.4926 \mathrm{~g}(98 \%)$ of an oily product $\left([\alpha]_{D}^{26}-30\right.$ $\left.\left(26^{\circ} \mathrm{C}\right)\left(c 0.99, \mathrm{CHCl}_{3}\right)\right)$ : ${ }^{1} \mathrm{H}-\mathrm{NMR} \delta\left(\mathrm{CDCl}_{3}\right)$ 6.8-6.4 (m, 1 $\mathrm{H}), 5.9(\mathrm{sl}, 2 \mathrm{H}), 4.15(\mathrm{dd}, 1 \mathrm{H}, J=7.1 \mathrm{~Hz}$ and $J=9.3 \mathrm{~Hz})$, $3.85(\mathrm{dd}, 1 \mathrm{H}, J=7.1 \mathrm{~Hz}$ and $J=9.1 \mathrm{~Hz}), 3.0(\mathrm{dd}, 1 \mathrm{H}, J=$ $5.1 \mathrm{~Hz}$ and $J=14.2 \mathrm{~Hz}), 2.85(\mathrm{dd}, 1 \mathrm{H}, J=7.3 \mathrm{~Hz}$ and $J=$ $14.2 \mathrm{~Hz}), 2.6$ (d, $1 \mathrm{H}, J=7.1 \mathrm{~Hz}), 2.55(\mathrm{~m}, 1 \mathrm{H}), 2.45(\mathrm{~d}, 1 \mathrm{H}$, $J=8,6 \mathrm{~Hz}), 2.4(\mathrm{~m}, 1 \mathrm{H}) ;{ }^{13} \mathrm{C}-\mathrm{NMR} \delta\left(\mathrm{CDCl}_{3}\right) 178.4,147.9$, $147.8,146.5,146.4,131.6,131.3,122.2,121.55,109.4,108.8$, $108.4,108.3,101.0,71.2,46.4,41.3,38.4,34.8$ [9].

\section{Chemicals and culture media}

Dimethylsulfoxide (DMSO), nicotinamide adenine dinucleotide phosphate sodium salt (NADP), D-glucose-6-phosphate disodium salt, magnesium chloride, L-histidine monohydrate, D-biotin, 4-nitro-o-phenylenediamine (NOPD), sodium azide (SA), mitomycin $\mathrm{C}(\mathrm{MMC})$, benzo[a]pyrene $(\mathrm{B}[a] \mathrm{P})$, aflatoxin $\mathrm{B}_{1}\left(\mathrm{AFB}_{1}\right)$, 2-amino-anthracene (2-AA) and 2-amino-fluorene (2-AF) were purchased from Sigma Chemical Co. (St. Louis, MO, USA). Doxorubicin (DXR) was purchased from Pharmacia Brasil Ltda, Brazil, and dissolved in distilled water immediately before treatment. Oxoid Nutrient Broth No. 2 (Oxoid, England) and Difco Bacto Agar (Difco, USA) were used as bacterial media. D-glucose, magnesium sulfate, citric acid monohydrate, anhydrous dibasic potassium phosphate, sodium ammonium phosphate, monobasic sodium phosphate, dibasic sodium phosphate and sodium chloride were purchased from Merck (Whitehouse Station, NJ, USA).

\section{Cell line and culture conditions}

Chinese hamster lung fibroblasts (V79) were kindly supplied by Professor Cólus (Universidade Estadual de Londrina (UEL), Paraná, Brazil). Cells were maintained 
as monolayers in plastic culture flasks $\left(25 \mathrm{~cm}^{2}\right)$ in HAM-F10 (Sigma-Aldrich) plus DMEM (Sigma-Aldrich, $1: 1)$ culture medium supplemented with $10 \%$ fetal bovine serum (Nutricell), antibiotics $\left(0.01 \mathrm{mg} \mathrm{mL}^{-1}\right.$ streptomycin and $0.005 \mathrm{mg} \mathrm{mL}^{-1}$ penicillin; Sigma-Aldrich) and 2.38 $\mathrm{mg} \mathrm{mL}{ }^{-1}$ Hepes (Sigma-Aldrich), at $37^{\circ} \mathrm{C}$ in a BOD-type chamber. Under these conditions, the average cell cycle time was $12 \mathrm{~h}$.

\section{Comet assay}

The protocol for the determination of the genotoxicity and antigenotoxicity of $\mathrm{HK}$ at various concentrations $(0.5-128 \mu \mathrm{M})$ was performed in triplicate on three different days, to ensure reproducibility. HK was first dissolved in a mixture of methanol $(100 \mu \mathrm{L})$ and distilled water $(900 \mu \mathrm{L})$. The final concentration of methanol in the culture was $0.1 \%$. The choice of concentrations was based on the results of previous experiments with $\mathrm{HK}$ [12]. In the experiments, $3 \times 10^{5}$ cells (V79) were seeded into tissue-culture flasks, incubated for two cycles $(24 \mathrm{~h})$ in complete HAM-F10/DMEM medium, washed with phosphate buffer saline (PBS), and then subjected to one of the following treatments, in serum-free medium, for 3 h. To assess genotoxicity, the cells were treated with each concentration of HK alone, while for antigenotoxicity, they were treated with the mutagen DXR $(0.3 \mu \mathrm{M})$ in combination with each $\mathrm{HK}$ concentration. Positive (DXR) and negative controls were also included in the test. At the end of the treatment, the cells were washed with ice-cold PBS and trypsinized with $200 \mu \mathrm{L}$ trypsin. After $3 \mathrm{~min}$, the cells were gently resuspended in complete medium and $20 \mu \mathrm{L}$ of the cell suspension was immediately used for the test.

The procedures described by Singh et al. [14] were adopted, with minor modifications, as described in detail by Speit and Hartmann [15] and reviewed by Burlinson et al. [16]. Briefly, a microscope slide was covered with a base layer of $1.5 \%$ normal-melting agarose (Invitrogen) and $20 \mu \mathrm{L}$ of the test cells suspended in $120 \mu \mathrm{L} 0.5 \%$ low-melting agarose (Invitrogen) at $37^{\circ} \mathrm{C}$ was then spread over the base layer. A coverslip was added and the agarose allowed to solidify at $4^{\circ} \mathrm{C}$ for $15 \mathrm{~min}$. Next, the coverslip was gently removed and the slides were immersed in freshly prepared lysing solution consisting of $89 \mathrm{~mL}$ stock solution $(2.5 \mathrm{M} \mathrm{NaCl}, 100 \mathrm{mM}$ EDTA,

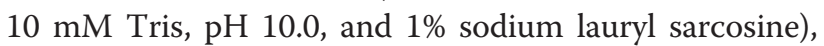
$10 \mathrm{~mL}$ DMSO and $1 \mathrm{~mL}$ Triton $\mathrm{X}-100, \mathrm{pH} 10.0$, at $4^{\circ} \mathrm{C}$, for at least $20 \mathrm{~h}$, protected from light. At the end of this period, the slides were transferred to an electrophoresis chamber containing a high $\mathrm{pH}(>13.0)$ buffer $(300 \mathrm{mM}$ $\mathrm{NaOH}, 1 \mathrm{mM}$ EDTA) and incubated at $4^{\circ} \mathrm{C}$ for $20 \mathrm{~min}$ to allow the DNA to unwind. A current of $25 \mathrm{~V}\left(1.0 \mathrm{~V} \mathrm{~cm}^{-1}\right.$, $300 \mathrm{~mA}$ ) was applied for $20 \mathrm{~min}$. The slides were then submerged in a neutralization buffer $(0.4 \mathrm{M}$ Tris - $\mathrm{HCl}$,
$\mathrm{pH}$ 7.5) for $15 \mathrm{~min}$, dried at room temperature and fixed in $100 \%$ ethanol for $10 \mathrm{~min}$.

The slides were stained with $100 \mu \mathrm{L}$ ethidium bromide $\left(20 \mu \mathrm{g} \mathrm{ml}^{-1}\right)$ and covered with a coverslip. All the slides in the experiment were coded before analysis. The stained nucleoids were immediately evaluated at $1000 \mathrm{x}$ magnification under a Nikon fluorescence microscope fitted with a 515-560 nm excitation filter and a $590 \mathrm{~nm}$ barrier filter.

For each treatment, the extent and distribution of DNA damage indicated by the comet assay were evaluated by examining 100 randomly selected and non-overlapping cells on the slides (i.e. 300 nucleoids per treatment). For each slide, the cells were visually scored and allocated to one of four classes ( $0,1,2$ and 3$)$, according to tail size, as follows: class 0 , undamaged, no tail; class 1 , a short tail whose length was smaller than the diameter of the comet head (nucleus); class 2, tail length between 1 and 2 times the diameter of the head; and class 3, maximally damaged: a long tail measuring more than twice the diameter of the head. The few comets containing no head and those with almost all DNA in the tail, or with a very wide tail, were excluded from the analysis since they may arise from dead cells [17].

The total score for 300 comets was calculated by the formula shown below:

$$
\text { Score }=\left(1 \times n_{1}\right)+\left(2 \times n_{2}\right)+\left(3 \times n_{3}\right)
$$

where $n=$ number of cells in each class analyzed. Thus, the total score ranged from 0 to 300 . The percentage reduction of genotoxic agent-induced damage by $\mathrm{HK}$ was calculated as in Waters et al. [18], with the following formula:

$$
\% \text { Reduction }=(A-B / A-C) \times 100
$$

where $A$ is the mean score in the treatment with DXR (positive control), $B$ the mean score in the antigenotoxic treatment (HK plus DXR) and $C$ the mean score in the negative control.

Cell viability was evaluated for each treatment by Trypan blue staining. Briefly, a solution of $50 \mu \mathrm{L}$ Trypan blue $(0.4 \%)$ freshly prepared in distilled water was mixed with $50 \mu \mathrm{L}$ of each cell suspension, spread onto a microscope slide and covered with a coverslip. Non-viable cells appeared blue. At least 200 cells were counted per culture.

The results were evaluated by analysis of variance (ANOVA) and the Tukey test at $P<0.05$, the experimental criterion being the significance of the response to $\mathrm{HK}$ treatment in relation to the negative control, in the genotoxicity assay, and in relation to the positive control when the antigenotoxicity of $\mathrm{HK}$ was determined as its capacity to reduce the DNA damage induced by DXR. 


\section{Ames test}

Mutagenic activity was evaluated by the Salmonella/ microsome assay, using the Salmonella typhimurium tester strains TA98, TA100, TA97a and TA102, kindly provided by Dr. B.N. Ames (Berkeley, CA, USA), with (+ S9) and without (- S9) metabolization, by the pre-incubation method [19]. The strains were grown from frozen cultures overnight for 12-14 h in Oxoid Nutrient Broth No. 2. The metabolic activation mixture (S9 fraction), prepared from livers of Sprague-Dawley rats treated with the polychlorinated biphenyl mixture Aroclor 1254 (500 mg/ kg), was purchased from Molecular Toxicology Inc. (Boone, NC, USA) and freshly prepared before each test. The metabolic activation system consisted of 4\% S9 fraction, $1 \% 0.4 \mathrm{M} \mathrm{MgCl}_{2}, 1 \% 1.65 \mathrm{M} \mathrm{KCl}, 0.5 \% 1 \mathrm{M} \mathrm{D}$-glucose6-phosphate disodium and 4\% $0.1 \mathrm{M}$ NADP, 50\% $0.2 \mathrm{M}$ phosphate buffer and $39.5 \%$ sterile distilled water [19].

For the determination of the mutagenic activity, five different concentrations of HK (9.75 - 78.0 $\mu \mathrm{g}$ ( plate), diluted in DMSO, were assayed. The concentrations of HK were selected on the basis of a preliminary toxicity test. In all subsequent assays, the upper limit of the dose range tested was either the highest non-toxic dose or the lowest toxic dose determined in this preliminary assay. Toxicity was detected either as a reduction in the number of histidine revertants (His+), or as a thinning of the auxotrophic background (i.e., background lawn). The various concentrations of $\mathrm{HK}$ to be tested were added to $0.5 \mathrm{~mL}$ of $0.2 \mathrm{M}$ phosphate buffer, or to $0.5 \mathrm{~mL}$ of $4 \% \mathrm{~S} 9$ mixture, with $0.1 \mathrm{~mL}$ of bacterial culture and then incubated at $37^{\circ} \mathrm{C}$ for 20-30 min. Next, $2 \mathrm{~mL}$ of top agar was added and the mixture poured on to a plate containing minimal agar.

The plates were incubated at $37^{\circ} \mathrm{C}$ for $48 \mathrm{~h}$ and the His+ revertant colonies were counted manually. All experiments were analyzed in triplicate. The results were analyzed with the statistical software package Salanal 1.0 (U.S. Environmental Protection Agency, Monitoring Systems Laboratory, Las Vegas, NV,from Research Triangle Institute, RTP,NC, USA), adopting the Bernstein et al. [20] model. The data (revertants/ plate) were assessed by analysis of variance (ANOVA), followed by linear regression. The mutagenic index (MI) was also calculated for each concentration tested, this being the average number of revertants per plate with the test compound divided by the average number of revertants per plate with the negative (solvent) control. A test solution was considered mutagenic when a dose-response relationship was detected and a two-fold increase in the number of mutants $(\mathrm{MI} \geq 2)$ was observed for at least one concentration [21]. The standard mutagens used as positive controls in experiments without S9 mix were NOPD (10 $\mu$ g/ plate) for TA98 and TA97a, SA $(1.25 \mu \mathrm{g} /$ plate $)$ for TA100 and MMC $(0.5 \mu \mathrm{g} /$ plate $)$ for TA102. In experiments with S9 activation, 2-AA (1.25 $\mu \mathrm{g}$ /plate) was used with TA98, TA97a and TA100 and 2-AF
(10 $\mu \mathrm{g} /$ plate) with TA102. DMSO $(50 \mu \mathrm{L} /$ plate $)$ served as the negative (solvent) control.

The antimutagenicity assay was conducted by means of the same procedure as the mutagenicity assay, except that HK was associated with known mutagens in tests with and without metabolic activation. In these tests, the direct-acting mutagens were $10.0 \mu \mathrm{g} /$ plate of NOPD (for S. typhimurium TA98 and TA97a), $1.25 \mu \mathrm{g} /$ plate of SA (for S. typhimurium TA100) and $0.5 \mu \mathrm{g} /$ plate of MMC (for S. typhimurium TA102), in the assay without metabolic activation, and the indirect-acting mutagens were $1.0 \mu \mathrm{g} /$ plate of $\mathrm{B}[a] \mathrm{P}$ (for $S$. typhimurium TA98), $0.5 \mu \mathrm{g} /$ plate of $\mathrm{AFB}_{1}$ (for S. typhimurium TA100), 1.25 $\mu \mathrm{g} /$ plate of 2-AA (for S. typhimurium TA97a) and 10 $\mu \mathrm{g} /$ plate of 2-AF (for S. typhimurium TA102), in the assay with metabolic activation. All the plates were incubated at $37^{\circ} \mathrm{C}$ for 48 hours, and the number of revertant colonies per plate was counted manually. The entire assay was performed in triplicate.

The antimutagenicity results were expressed as percent inhibition (the ability of the compounds to inhibit the action of the known mutagen). This was calculated as follows:

$$
\operatorname{Inhibition}(\%)=100-[(T / M) \times 100]
$$

where $T$ is the number of revertant colonies in the plate containing mutagen and compounds and $M$ is the number of revertant colonies in the plate containing only the mutagen [22].

No antimutagenic effect was recorded when the inhibition was lower than $25 \%$, a moderate effect for a value between $25 \%$ and $40 \%$, and strong antimutagenicity for values greater than $40 \%$ [23,24].

Cell viability was also determined for each antimutagenesis experiment, to assess the potential bactericidal effect of the mutagens. A substance was considered bactericidal when the bacterial survival was less than $60 \%$ of that observed in the negative control $[24,25]$.

\section{Results}

\section{Comet assay}

The results for V79 cells treated with HK by comet assay are shown in Table 1 . No significant difference was observed between cultures treated with $\mathrm{HK}$ and the negative control group $(P>0.05)$, demonstrating the absence of genotoxicity. On the other hand, a significant increase in the rate of DNA damage was observed in cultures treated with DXR, relative to the negative control, as expected.

In the treatments with HK associated with DXR, the lower concentrations of $\mathrm{HK}(0.5 ; 1.0$ and $2.0 \mu \mathrm{M})$ significantly reduced the extent of DNA damage induced by DXR. This significant reduction in the frequency of DNA damage ranged from 60.8 to $76.0 \%$. The gradual increase 
Table 1 DNA migration in the comet assay from V79 cells treated with various doses of HK and/or DXR and their respective controls

\begin{tabular}{|c|c|c|c|c|c|c|}
\hline \multirow{2}{*}{$\begin{array}{l}\text { Treatments } \\
(\mu \mathrm{M})\end{array}$} & \multicolumn{4}{|l|}{ Class $^{*}$} & \multirow[t]{2}{*}{ Score $^{*}$} & \multirow[t]{2}{*}{ Reduction \% } \\
\hline & 0 & 1 & 2 & 3 & & \\
\hline Control & $84.3 \pm 9.0$ & $10.0 \pm 4.0$ & $2.3 \pm 2.0$ & $1.6 \pm 2.0$ & $20.3 \pm 13.0$ & - \\
\hline $\mathrm{MeOH}$ & $87.0 \pm 7.0$ & $11.0 \pm 5.5$ & $2.3 \pm 1.5$ & 0 & $18.0 \pm 5.1$ & - \\
\hline 0.5 & $81.6 \pm 4.9$ & $12.3 \pm 3.5$ & $4.3 \pm 3.7$ & $5.0 \pm 2.8$ & $26.0 \pm 13.2$ & - \\
\hline 1.0 & $87.0 \pm 5.1$ & $11.0 \pm 5.2$ & $1.3 \pm 0.5$ & 0 & $13.0 \pm 5.0$ & - \\
\hline 2.0 & $83.0 \pm 3.7$ & $14.0 \pm 2.5$ & $2.0 \pm 2.0$ & 0 & $18.0 \pm 5.0$ & - \\
\hline 32 & $89.0 \pm 2.0$ & $10.0 \pm 2.0$ & $0.3 \pm 0.5$ & $0.6 \pm 1.1$ & $9.6 \pm 2.3$ & - \\
\hline 64 & $88.0 \pm 3.6$ & $11.0 \pm 4.0$ & $0.6 \pm 1.0$ & $1.0 \pm 1.0$ & $13.0 \pm 3.4$ & - \\
\hline 128 & $89.0 \pm 1.5$ & $10.0 \pm 1.5$ & $1.0 \pm 0.0$ & 0 & $12.0 \pm 1.5$ & - \\
\hline DXR & $41.0 \pm 12.0$ & $36.0 \pm 12.7$ & $18.0 \pm 2.0$ & $4.0 \pm 2.5$ & $86.0 \pm 11.5^{\mathrm{a}}$ & - \\
\hline $\mathrm{DXR}+\mathrm{MeOH}$ & $46.3 \pm 6.8$ & $30.0 \pm 6.0$ & $16.3 \pm 5.6$ & $6.6 \pm 3.0$ & $83.3 \pm 14.5^{\mathrm{a}}$ & - \\
\hline $0.5+\mathrm{DXR}$ & $73.0 \pm 7.0$ & $20.0 \pm 7.5$ & $4.6 \pm 1.5$ & $2.0 \pm 2.0$ & $36.0 \pm 6.1^{a, b}$ & 76.0 \\
\hline $1.0+\mathrm{DXR}$ & $68.0 \pm 2.0$ & $20.6 \pm 2.5$ & $8.0 \pm 2.0$ & $3.3 \pm 0.5$ & $46.0 \pm 3.0^{a, b}$ & 60.8 \\
\hline $2.0+D X R$ & $65.0 \pm 6.8$ & $27.0 \pm 6.6$ & $4.3 \pm 2.3$ & $2.6 \pm 1.6$ & $44.3 \pm 9.2^{a, b}$ & 63.4 \\
\hline $32+D X R$ & $35.0 \pm 5.0$ & $33.0 \pm 3.0$ & $30.0 \pm 4.1^{b}$ & $1.0 \pm 1.0$ & $97.0 \pm 10.0^{\mathrm{a}}$ & - \\
\hline $64+D X R$ & $32.0 \pm 6.1$ & $39.0 \pm 3.7$ & $26.0 \pm 2.0$ & $2.0 \pm 2.0$ & $97.0 \pm 10.0^{a}$ & - \\
\hline $128+\mathrm{DXR}$ & $28.0 \pm 6.6$ & $40.0 \pm 1.0$ & $29.0 \pm 5.2^{b}$ & $3.0 \pm 2.5$ & $106.0 \pm 16.0^{a}$ & - \\
\hline
\end{tabular}

$\mathrm{HK}=(-)$-hinokinin; $\mathrm{MeOH}=$ methanol $(0.1 \%) ; \mathrm{DXR}=$ doxorubicin $(0.3 \mu \mathrm{M})$.

The different doses $(0.5,1.0,2.0,32,64$ and $128 \mu \mathrm{M})$ correspond to HK.

*Values are the means \pm standard deviation.

a Significantly different from control $(P<0.05)$.

${ }^{b}$ Significantly different from the DXR group $(P<0.05)$.

in the concentration of HK did not lead to a proportional increase in the reduction of DXR-induced genotoxicity, thus demonstrating the absence of a dose-response relationship (Table 1).

However, at the higher concentrations of HK $(32 ; 64$ and $128 \mu \mathrm{M}$ ) associated with DXR, the extent of DNA damage did not differ significantly from the frequencies observed in the DXR treatment. The data also showed that the extent of class 2 damage was higher in treatments with HK and DXR than in the group treated with DXR, which was statistically significant at concentrations of 32 and $128 \mu \mathrm{M}$ (Table 1 ).

Comet class 0 was the most frequent among cultures treated with various doses of $\mathrm{HK}$, negative and solvent controls, and lower concentrations of HK plus DXR, whereas comet classes 1 and 2 were the most frequent among cultures treated with only with DXR or $\mathrm{MeOH}$ plus DXR (Table 1). Cell viability was higher than $95 \%$ in all treatments.

There was no significant difference in the extent of DNA damage between cultures treated with the solvent plus DXR and the positive control.

\section{Ames test}

Table 2 shows the mean number of revertants/plate (M), the standard deviation (SD) and the mutagenic index
(MI) after the treatments with HK, observed in $S$. typhimurium strains TA98, TA100, TA102 and TA97a, in the presence $(+\mathrm{S} 9)$ and absence $(-\mathrm{S} 9)$ of metabolic activation. The mutagenicity assays show that HK did not induce any increase in the number of revertant colonies relative to the negative control, indicating the absence of any mutagenic activity.

On the other hand, the results obtained in the tests for antimutagenic potential of $\mathrm{HK}$, presented in Table 3, show a strong inhibitory effect against direct and indirect-acting mutagens, for strains TA98, TA100, TA102 and TA97a. The results are expressed as mean number of revertants/ plate $(\mathrm{M})$, the standard deviation (SD) and the percent inhibition of mutagenic activity of a sample containing a mixture of mutagen and $\mathrm{HK}$, relative to the mutagenicity of the mutagen alone.

When strain TA98 was used in association with NOPD, a moderate antimutagenic effect was observed for $\mathrm{HK}$ (26\% inhibition). In experiments with metabolic activation, for strain TA98, the mutagenicity of $\mathrm{B}[a] \mathrm{P}$ was significantly reduced by $59 \%$.

$\mathrm{HK}$ did not reduce mutagenesis induced by SA, MMC or NOPD, in the absence of metabolic activation, when strains TA100, TA102 and TA97a were used, respectively. However, HK did inhibit mutation induced by the 
Table 2 Revertants/ plate, standard deviation and mutagenicity index (in brackets) for the strains TA98, TA100, TA102 and TA97a of S. typhimurium after treatment with various doses of HK, with (+S9) and without (-S9) metabolic activation

\begin{tabular}{|c|c|c|c|c|c|c|c|c|c|}
\hline & \multirow{3}{*}{$\begin{array}{l}\text { Treatments } \\
\mu \mathrm{g} / \text { plate }\end{array}$} & \multicolumn{8}{|c|}{ Number of revertants $(M \pm S D) /$ plate and $M I$} \\
\hline & & \multicolumn{2}{|c|}{ TA 98} & \multicolumn{2}{|l|}{ TA 100} & \multicolumn{2}{|l|}{ TA 102} & \multicolumn{2}{|l|}{ TA 97a } \\
\hline & & -59 & $+\mathrm{S9}$ & -59 & $+\mathrm{S9}$ & -59 & $+\mathrm{S9}$ & -59 & $+\$ 99$ \\
\hline \multirow[t]{7}{*}{ HK } & $0.0^{\mathrm{a}}$ & $22 \pm 2$ & $32 \pm 1$ & $132 \pm 6$ & $123 \pm 1$ & $243 \pm 4$ & $391 \pm 8$ & $164 \pm 4$ & $163 \pm 2$ \\
\hline & 9.7 & $18 \pm 4(0.8)$ & $32 \pm 1(1.0)$ & $134 \pm 4(1.0)$ & $130 \pm 6(1.1)$ & $238 \pm 8(1.0)$ & $376 \pm 7(1.0)$ & $165 \pm 5(1.0)$ & $172 \pm 10(1.0$ \\
\hline & 19.5 & $23 \pm 3(1.0)$ & $34 \pm 3(1.1)$ & $129 \pm 6(1.0)$ & $128 \pm 6(1.0)$ & $231 \pm 8(0.9)$ & $363 \pm 3(0.9)$ & $165 \pm 9(0.9)$ & $187 \pm 3(1.1)$ \\
\hline & 39.0 & $25 \pm 3(1.1)$ & $33 \pm 4(1.0)$ & $134 \pm 5(1.0)$ & $115 \pm 8(0.9)$ & $213 \pm 4(0.9)$ & $354 \pm 4(0.9)$ & $146 \pm 5(0.9)$ & $166 \pm 5(1.0)$ \\
\hline & 58.5 & $25 \pm 2(1.1)$ & $28 \pm 1(0.8)$ & $112 \pm 3(0.8)$ & $134 \pm 2(1.1)$ & $201 \pm 6(0.8)$ & $398 \pm 9(1.0)$ & $175 \pm 4(1.1)$ & $172 \pm 2(1.0)$ \\
\hline & 78.0 & $24 \pm 5(1.1)$ & $31 \pm 2(1.0)$ & $140 \pm 9(1.1)$ & $120 \pm 8(1.0)$ & $186 \pm 2(0.8)$ & $402 \pm 3(1.0)$ & $163 \pm 8(1.0)$ & $146 \pm 4(0.9)$ \\
\hline & Ctrol + & $1347 \pm 88^{b}$ & $1567 \pm 115^{e}$ & $1582 \pm 98^{c}$ & $1456 \pm 78^{e}$ & $1656 \pm 60^{d}$ & $1932 \pm 97^{f}$ & $1766 \pm 49^{b}$ & $1789 \pm 89^{e}$ \\
\hline
\end{tabular}

$\mathrm{HK}=(-)$-Hinokinin; $\mathrm{M} \pm \mathrm{SD}=$ mean and standard deviation; $\mathrm{MI}=$ mutagenicity index; ${ }^{\mathrm{a}}$ Negative control: dimethylsulfoxide (DMSO - $\left.50 \mu \mathrm{L} / \mathrm{plate}\right) ; \mathrm{Ctrol}+=\mathrm{Positive}$ control - ${ }^{b} 4$-nitro-o-phenylenediamine (NOPD - $10.0 \mu \mathrm{g} /$ plate - TA98, TA97a); ${ }^{c}$ sodium azide (1.25 $\left.\mu \mathrm{g} / \mathrm{plate}-\mathrm{TA100}\right) ;{ }^{\mathrm{d}} \mathrm{mitomycin}(0.5 \mu \mathrm{g} / \mathrm{plate}-\mathrm{TA} 102)$, in the absence of $\mathrm{S} 9$ and ${ }^{\mathrm{e}} 2$-anthramine $\left(1.25 \mu \mathrm{g} /\right.$ plate - TA 97a, TA98, TA100); ${ }^{\mathrm{f}} 2$-aminofluorene $(10.0 \mu \mathrm{g} /$ plate - TA102), in the presence of S9.

alkylating agent $\mathrm{AFB}_{1}$ in TA100, produced significant decreases in the mutagenicity of 2-AF in TA102 (52\%) and a strong antimutagenic effect against mutations induced by 2 -AA in TA97a (67\% inhibition). The highest observed percent inhibition of mutagenicity (89\%) achieved with HK was in strain TA100, in the presence of $\mathrm{AFB}_{1}$. Furthermore, HK potentiated NOPD -induced clastogenicity in the strain 97a: the number of revertents observed for the combined treatment was higher than that observed for the positive control alone.

Table 3 Antimutagenic activity expressed as the mean and standard deviation of number of revertants and percent inhibition by HK of direct (-S9) and indirect (+S9) mutagens, tested on strains TA98, TA100, TA102 and TA 97 a of S. typhimurium

\begin{tabular}{|c|c|c|c|c|c|c|c|c|}
\hline \multirow{3}{*}{$\begin{array}{c}\text { Treatments } \\
\mathrm{HK} \\
\mu \mathrm{g} / \text { plate }\end{array}$} & \multicolumn{8}{|c|}{ Number of revertants $(M \pm S D) /$ plate and $\%$ of inhibition } \\
\hline & \multicolumn{4}{|c|}{ TA 98} & \multicolumn{4}{|c|}{ TA 100} \\
\hline & - S9 & $\%$ inhibition & + S9 & $\%$ inhibition & - S9 & $\%$ inhibition & + S9 & $\%$ inhibition \\
\hline \multirow[t]{2}{*}{ Ctrol + } & NOPD & & $\mathrm{B}[a] \mathrm{P}$ & & SA & & $\mathrm{AFB}_{1}$ & \\
\hline & $638 \pm 30$ & & $1244 \pm 38$ & & $1219 \pm 46$ & & $1607 \pm 79$ & \\
\hline 9.7 & $525 \pm 7$ & $18^{*}$ & $874 \pm 21$ & $31^{* *}$ & $1139 \pm 20$ & $7^{*}$ & $1183 \pm 30$ & $30^{* *}$ \\
\hline 19.5 & $507 \pm 15$ & $21^{*}$ & $869 \pm 4$ & $32^{* *}$ & $1112 \pm 34$ & $9^{*}$ & $976 \pm 18$ & $45^{* * *}$ \\
\hline 39.0 & $477 \pm 5$ & $26^{* *}$ & $813 \pm 18$ & $36^{* *}$ & $1169 \pm 32$ & $5^{*}$ & $943 \pm 11$ & $47^{* * *}$ \\
\hline 58.5 & $521 \pm 9$ & $19^{*}$ & $618 \pm 6$ & $52^{* * *}$ & $1145 \pm 16$ & $7^{*}$ & $612 \pm 33$ & $71^{* * *}$ \\
\hline \multirow[t]{2}{*}{78.0} & $480 \pm 16$ & $25^{* *}$ & $539 \pm 32$ & $59^{* * *}$ & $1181 \pm 41$ & $3^{*}$ & $354 \pm 22$ & $89^{* * *}$ \\
\hline & \multicolumn{4}{|c|}{ TA 102} & \multicolumn{4}{|c|}{ TA 97a } \\
\hline$\mu \mathrm{g} /$ plate & - S9 & $\%$ inhibition & + S9 & $\%$ inhibition & - S9 & $\%$ inhibition & + S9 & $\%$ inhibition \\
\hline \multirow[t]{2}{*}{ Ctrol + } & MMC & & $2-A F$ & & NOPD & & 2-AA & \\
\hline & $1184 \pm 42$ & & $1279 \pm 12$ & & $884 \pm 34$ & & $1083 \pm 67$ & \\
\hline 9.7 & $1236 \pm 17$ & - & $852 \pm 21$ & $42^{* * *}$ & $934 \pm 33$ & - & $682 \pm 52$ & $43^{* * *}$ \\
\hline 19.5 & $1201 \pm 23$ & - & $855 \pm 22$ & $42^{* * *}$ & $948 \pm 24$ & - & $659 \pm 41$ & $45^{* * *}$ \\
\hline 39.0 & $1317 \pm 14$ & - & $820 \pm 19$ & $46^{* * *}$ & $979 \pm 84$ & - & $628 \pm 16$ & $49^{* * *}$ \\
\hline 58.5 & $1017 \pm 56$ & $18^{*}$ & $754 \pm 9$ & $52^{* * *}$ & $1006 \pm 54$ & - & $456 \pm 13$ & $67^{* * *}$ \\
\hline 78.0 & $979 \pm 51$ & $22^{*}$ & $757 \pm 29$ & $52^{* * *}$ & $1026 \pm 75$ & - & $523 \pm 86$ & $60 * * *$ \\
\hline
\end{tabular}

$\mathrm{HK}=(-)$-Hinokinin; $\mathrm{M} \pm \mathrm{SD}=$ mean and standard deviation; Ctrol + = positive Control; NOPD = 4 -nitro-o-phenylenediamine (10.0 $\mu \mathrm{g} /$ plate - TA98 and TA97a); $\mathrm{SA}=$ sodium azide $(1.25 \mu \mathrm{g} /$ plate $-\mathrm{TA} 100) ; \mathrm{MMC}=$ mitomycin $(0.5 \mu \mathrm{g} /$ plate $-\mathrm{TA} 102)$, in the absence of $\mathrm{S} 9$ and $\mathrm{B}[a] \mathrm{P}=\mathrm{benzo}[a] \mathrm{pyrene}(1.0 \mu \mathrm{g} / \mathrm{plate}-\mathrm{TA} 98) ;$ $\mathrm{AFB}_{1}=$ aflatoxin $\mathrm{B}_{1}(0.5 \mu \mathrm{g} /$ plate $-\mathrm{TA} 100) ; 2$-AA $=2$-anthramine $(1.25 \mu \mathrm{g} /$ plate $-\mathrm{TA} 97 \mathrm{a}) ; 2$-AF = 2-aminofluorene $(10.0 \mu \mathrm{g} / \mathrm{plate}-\mathrm{TA} 102)$, in the presence of $\mathrm{S} 9$.

* no antimutagenic effect $(<25 \%$ inhibition).

** moderate effect $(25 \%-40 \%$ inhibition).

*** strong antimutagenic effect ( $>40 \%$ inhibition). 


\section{Discussion}

The balance between the therapeutic and toxicological effects of a compound is a very important measure of the usefulness of a pharmacological drug. Therefore, the determination of the potential mutagenic effect of any drug under development is mandatory [26].

In previous studies, Medola et al. [1] showed that HK not only had no genotoxic effect, but also was effective in reducing the chromosome damage induced by DXR, by the rat peripheral blood micronucleus test. Recently, Resende et al. [12] assessed the possible genotoxic activity of $\mathrm{HK}$ and its influence on the activities of two known mutagenic agents (DXR and methyl methanesulfonate MMS), in the micronucleus test with Chinese hamster lung fibroblast V79 cells. HK alone had no genotoxic effect under the conditions tested, but it reduced the chromosome damage caused by MMS. The reduction in DXR-induced clastogenicity was observed at lower concentrations. At higher concentrations, HK acted as a potentiator of DXR-induced clastogenicity, with the observation of a significantly higher frequency of micronuclei in the combined treatment when compared to the positive control.

To complement the above results, the genotoxid mutagenic activities of $\mathrm{HK}$, and its influence on the activities of known mutagenic agents, were assessed by comet and Ames test in this study. According to Witte et al. [27], experience with genetic toxicology testing over the past few decades has demonstrated that no single test method is capable of detecting all types of genotoxic effects. Therefore, the potential for a chemical to cause genotoxicity is typically determined by using a battery of in vitro and in vivo tests.

Through the comet assay, the first and extremely important observation was the absence of DNA strand breaks; moreover, there were no gene mutations by the Ames test in the presence and absence of metabolic activation. The performance of assays for to assess mutagenicity, as well as other risks, is essential, given the potential consumption of HK by the population. The absence of genotoxic mutagenic effects by HK on V79 cells in the comet test and against $S$. typhimurium bacterial strains in the Ames test is a positive step towards ensuring its safe use in medicine. Considering the possible use of $\mathrm{HK}$ as an antichagasic drug, a lack of mutagenic effects in animal cells and bacteria is highly relevant.

On the other hand, the influence of HK on DXRinduced DNA damage depends on the experimental conditions used and draws attention to the synergistic effect that HK may have when combined with other drugs. In the comet test, the lower concentrations of $\mathrm{HK}$ (0.5; 1.0 and $2.0 \mu \mathrm{M})$ significantly reduced the extent of DNA damage induced by DXR. However, the higher concentrations of $\mathrm{HK}(32 ; 64$ and $128 \mu \mathrm{M})$, when combined with DXR, showed a higher rate of class 2 damage than in the cells treated with DXR, which was statistically significant at concentrations of 32 and 128 $\mu \mathrm{M}$. However, the extent of DNA damage did not differ significantly from the frequencies observed in the DXR treatment. These results are consistent with Resende et al. [12], who assessed the influence of HK, at the same concentrations, on DXR-induced genotoxicity.

The chemical structure of DXR favors the generation of free radicals and the compound can bind to iron and form complexes with DNA, inducing DNA damage. Some studies have demonstrated that oxidative damage is probably related to this formation of free radicals accompanied by a reduction in antioxidant capacity [28]. Thus, at low concentrations, HK might possibly interfere in the intercalation of DXR with DNA or scavenge the generated free radicals. However, at higher doses, HK may increase the oxidative stress generated by DXR, since qualitative HPLC analysis showed that no new compound is formed after the incubation of a mixture of DXR and HK. HK may act as a "janus" compound, i.e., exerting an antioxidant effect at lower concentrations and a pro-oxidant effect at higher concentrations [12]. The synergistic effect also was observed when HK was combined with NOPD in the strain TA97a in the absence of metabolic activation in the Ames test, reinforcing the hypothesis that the HK may act as a "janus" compound.

In the antimutagenicity evaluated by Ames test, HK exhibited a protective effect in more than one test strain and acted against various mutational mechanisms. Among the antimutagenic activity against directly acting mutagens, a moderate effect was found only against frameshift mutations induced by NOPD in the TA98 strain, with the highest $\%$ of inhibition at concentration of $39.0 \mu \mathrm{g}$ / plate $(26 \%)$.

HK did not affect the SA-induced mutagenicity in strain TA100, MMC in strain TA102 or NOPD in strain 97a.

The protection of the bacterial genome against directly acting mutagens may be due to the rapid elimination of mutagens from the bacteria, before their interaction with the DNA [29]. HK may facilitate or stimulate the bacterial transmembrane export system to eliminate the mutagens; it may also interfere with the uptake of mutagens into bacteria $[29,30]$.

The activity displayed by HK was profoundly increased by incorporating the microsomal fraction (S9), which is a mammalian metabolic activation system, into the culture medium. The results of this experiment show that HK inhibited $\mathrm{B}[a] \mathrm{P}, \mathrm{AFB}_{1}, 2-\mathrm{AF}$ and 2- $\mathrm{AA}$ mediated mutagenesis. The microsomal fraction of rat liver, containing mixed-function oxidase (MFO) and the cytochromebased $\mathrm{P} 450$ metabolic oxidation system, can activate $\mathrm{B}[a]$ $\mathrm{P}$ to an active mutagen, benzo[a]pyrene-7,8-diol-9,10-epoxide [31]. The mutagenicity of $\mathrm{B}[a] \mathrm{P}$ was significantly 
reduced in a dose-dependent manner by 31 to $59 \%$ by HK.

This diol epoxide exerts its carcinogenic activity by alkylating nucleosides on DNA molecules at their bay region. The reaction occurs primarily with the purine bases, deoxyguanosine and deoxyadenosine, in DNA [32]. As a result, bulky stable and depurinating DNA adducts are formed [33,34]. Insufficient removal of these DNA adducts prior to replication creates hot spots in the gene and can result in deactivation of tumor suppressor genes or activation of oncogenes leading to tumor initiation $[35,36]$.

There are at least two possible mechanisms by which HK could decrease $\mathrm{B}[a] \mathrm{P}-\mathrm{DNA}$ adduct formation: by interacting with reactive intermediates or by interfering with the action of microsomal enzymes [36]. However, more studies are needed to confirm these ideas.

$\mathrm{HK}$ also reduced the frequency of mutations induced by the fungal toxin, $\mathrm{AFB}_{1}$, in TA100 with metabolic activation, resulting in the highest percent inhibition of mutagenicity (89\%). The S. typhimurium tester strain TA100 reveals base-pair-substitution point mutations [37].

Aflatoxins, a group of potent mycotoxins with mutagenic, carcinogenic, teratogenic, hepatotoxic and immunosuppressive properties, are of particular importance because of their adverse effects on animal and human health. Aflatoxins are produced as secondary metabolites by fungi of various species of Aspergillus (A. flavus, A. parasiticus and $A$. nomius) that grow on a variety of food and feed commodities. $\mathrm{AFB}_{1}$, which is the most toxic aflatoxin, is metabolized mainly in the liver to $\mathrm{AFB}_{1}$-8,9-exo-epoxide and 8,9-endo-epoxide. The exo-epoxide form of $\mathrm{AFB}_{1}$ binds to DNA to form the predominant 8,9-dihydro- 8(N7-guanyl)-9-hydroxy $\mathrm{AFB}_{1}$ adduct, leading to a more stable imidazole ring-opened $\mathrm{AFB}_{1}$-formamidopyrimidine adduct. The pseudo-half-life for loss of 8,9-dihydro-8- (N7-guanyl)-9-hydroxy $\mathrm{AFB}_{1}$ is short, but $\mathrm{AFB}_{1}-$ formamidopyrimidine adducts are stable, accumulate for several days and remain detectable for several weeks [38]. This aflatoxin is of particular interest because it is a frequent contaminant of many food products and one of the most potent naturally occurring mutagens and carcinogens known [39].

HK also induced a strong antimutagenic effect, significantly diminishing the mutagenicity of 2-AF in TA102 with metabolic activation, in a dose-dependent manner, by 42 to $52 \%$. 2 -AF is converted in rat liver, via $N$-hydroxy metabolites, to the reactive carcinogenic ester 2-acetylaminofluorene- $N$-sulfate, which can attack guanine residues in nucleic acids [31]. The inhibition of 2-AF induced mutagenicity may be mediated through the inhibition of the MFO (in the S9 fraction) or inactivation of the activated reactive ester of 2-AF. The S. typhimurium tester strain TA102 is normally used to detect mutagens that cause oxidative damage and base-pair-substitution mutations [37]. In this case, antimutagenic activity can be partially ascribed to antioxidant activity. This speculation is further supported by the significant antimutagenic effect that the lower concentrations of HK demonstrated against DXR in the comet test, as well as that against mutagens needing metabolic activation, where free radical generation is anticipated.

In this study, the antimutagenic property of HK related to its ability to modulate the xenobiotic-metabolizing enzymes in the liver, either by preventing the metabolic activation or by altering the enzymatic activity in the detoxification pathway to induce the disposal of the known mutagen [22], was again demonstrated by the results obtained with the mutagen 2-AA in strain TA97a with metabolic activation, where $67 \%$ inhibition was observed.

In general, inhibitors of mutagenesis can act in one of several ways: by inhibiting the interaction between genes and biochemically reactive mutagens; inhibiting metabolic activation of indirectly-acting mutagens by inactivation of metabolizing enzymes, or interacting with the pro-mutagens to make them unavailable for the enzymatic process [40].

\section{Conclusions}

In view of the above results and hypotheses, we can state that the inhibition of mutagenesis is often complex and involves multiple mechanisms. These results emphasize that antimutagenic mechanisms of HK cannot be generalized and that it is worth investigating each of them independently. The importance of this study is that HK no had to genotoxic / mutagenic effect in the comet and Ames assays and the DNA protective activity of $\mathrm{HK}$ is not general, therefore, this study demonstrates that besides the therapeutic potential for trypanosome diseases free of genotoxic / mutagenic effect, HK can provide a benefit antimutagenic effect, depending of the type of DNA damage-inducing agent used.

\section{Abbreviations}

HK: (-)-hinokinin; NOPD: 4- nitro-o-phenylenediamine; SA: Sodium azide; MMC: Mitomycin C; B[a]P: Benzo[a]pyrene; $\mathrm{AFB}_{1}$ : Aflatoxin $\mathrm{B}_{1} ; 2-\mathrm{AA}_{\mathrm{A}}$ 2aminoanthracene; 2-AF: 2-aminofluorene; DXR: Doxorubicin;

DMSO: Dimethylsulfoxide; PBS: Phosphate buffer saline; V79: Chinese hamster lung fibroblasts; +S9: With metabolization; -S9: Without metabolization; MI: Mutagenic index.

\section{Competing interests}

The authors declare that they have no competing interests.

\section{Authors' contributions}

FAR designed and performed the experiments, interpreted the results and drafted the manuscript. LCB and DCT designed and performed the comet assay. MSC participated in the experiments of the Ames test. KCSR and MLAS isolated the (-)-cubebin and prepared the (-)-hinokinin by partial synthesis. EAV critically read the manuscript and participated in revision of the manuscript. All authors have read and approved the final manuscript. 


\section{Acknowledgements}

This work was supported by "Fundação de Amparo à Pesquisa do Estado de São Paulo (FAPESP)" and "Coordenação de Aperfeiçoamento de Pessoal de Nível Superior (CAPES)", Brazilian state and federal agencies.

\section{Author details}

${ }^{1}$ Departamento de Ciências Biológicas, UNESP-Universidade Estadual Paulista Julio de Mesquita Filho- Faculdade de Ciências Farmacêuticas de Araraquara, Araraquara, São Paulo 14801-902, Brazil. ${ }^{2}$ Universidade de Franca, Franca, São Paulo 14404-600, Brazil.

Received: 20 August 2012 Accepted: 29 October 2012

Published: 31 October 2012

\section{References}

1. Medola JF, Cintra VP, Pesqueira E, Silva EP, de Andrade Royo V, da Silva R, Saraiva J, Albuquerque S, Bastos JK, Silva ML AE, Tavares DC: (-)-Hinokinin causes antigenotoxicity but not genotoxicity in peripheral blood of Wistar rats. Food Chem Toxicol 2007, 45:638-642.

2. Saraiva J, Vega C, Rolon M, da Silva R, Silva MLA, Donate PM, Bastos JK, Gomez-Barrio A, de Albuquerque S: In vitro and in vivo activity of lignan lactones derivatives against Trypanosoma cruzi. Parasitol Res 2007, 100:791-795.

3. Saraiva J, Lira AA, Esperandim VR, da Silva Ferreira D, Ferraudo AS, Bastos JK, Silva ML E, de Gaitani CM, de Albuquerque S, Marchetti JM: (-)-Hinokininloaded poly(D,-lactide-co-glycolide) microparticles for Chagas disease. Parasitol Res 2010, 106:703-708.

4. Paulino M, Iribarne F, Dubin M, Aguilera-Morales S, Tapia O, Stoppani AO The chemotherapy of Chagas' disease: an overview. Mini Rev Med Chem 2005, 5:499-519.

5. Cabrera M, Lavaggi ML, Hernandez P, Merlino A, Gerpe A, Porcal W, Boiani M, Ferreira A, Monge A, de Cerain Lopez A, Gonzalez M, Cerecetto H: Cytotoxic, mutagenic and genotoxic effects of new anti-T. cruzi 5phenylethenylbenzofuroxans. Contribution of phase I metabolites on the mutagenicity induction. Toxicol Lett 2009, 190:140-149.

6. Bartel LC, de Mecca Montalto M, Fanelli SL, de Castro Rodriguez C, Diaz EG, Castro JA: Early nifurtimox-induced biochemical and ultrastructural alterations in rat heart. Hum Exp Toxicol 2007, 26:781-788.

7. Da Silva Melo P, Duran N, Haun M: Cytotoxicity of Prodigiosin and Benznidazole on V79 cells. Toxicol Lett 2000, 116:237-242.

8. de Mecca Montalto M, Bartel LC, de Castro RC, Castro JA: Benznidazole biotransformation in rat heart microsomal fraction without observable ultrastructural alterations: comparison to Nifurtimox-induced cardiac effects. Mem Inst Oswaldo Cruz 2008, 103:549-553.

9. Souza VA, da Silva R, Pereira AC, Royo Vde A, Saraiva J, Montanheiro M, de Souza GH, da Silva Filho AA, Grando MD, Donate PM, Bastos JK, Albuquerque S, E-Silva ML: Trypanocidal activity of (-)-cubebin derivatives against free amastigote forms of Trypanosoma cruzi. Bioorg Med Chem Lett 2005, 15:303-307.

10. Silva ML, Coímbra HS, Pereira AC, Almeida VA, Lima TC, Costa ES, Vinhólis AH, Royo VA, Silva R, Filho AA, Cunha WR, Furtado NA, Martins CH, Carvalho TC, Bastos JK: Evaluation of piper cubeba extract, (-)-cubebin and its semi-synthetic derivatives against oral pathogens. Phytother Res 2007, 21:420-422.

11. Coimbra HS, Royo VA, Souza VA: Analgesic and anti-inflammatory activities of (-)-o benzyl cubebin, a (-)-cubebin derivative, obtained by partial synthesis. Boll Chim Farmac 2004, 2:65-69.

12. Resende FA, Tomazella IM, Barbosa LC, Ponce M, Furtado RA, Pereira AC, Bastos JK, Andrade E, Silva ML, Tavares DC: Effect of the dibenzylbutyrolactone lignan (-)-hinokinin on doxorubicin and methyl methanesulfonate clastogenicity in V79 Chinese hamster lung fibroblasts. Mutat Res 2010, 700:62-66.

13. Koul SK, Taneja SC, Dhar KL, Atal CK: Lignans of Piper clusii. Phytochem 1983, 22:999-1000.

14. Singh NP, McCoy MT, Tice RR, Schneider EL: A simple technique for quantitation of low levels of DNA damage in individual cells. Exp Cell Res 1988, 175:184-191

15. Speit $G$, Hartmann A: The comet assay (single-cell gel test). A sensitive genotoxicity test for the detection of DNA damage and repair. Methods Mol Biol 1999, 113:203-212.
16. Burlinson B, Tice RR, Speit G, Agurell E, Brendler-Schwaab SY, Collins AR, Escobar P, Honma M, Kumaravel TS, Nakajima M, Sasaki YF, Thybaud V, Uno Y, Vasquez M, Hartmann A: In Vivo Comet Assay Workgroup, part of the Fourth International Workgroup on Genotoxicity Testing. Fourth International Workgroup on Genotoxicity testing: results of the in vivo Comet assay workgroup. Mutat Res 2007, 627:31-35.

17. Hartmann A, Speit G: The contribution of citotoxicity of edible mushroom in a histidine-independent bacterial test system. Food Chem Toxicol 1997, 29:159-165.

18. Waters MD, Brady AL, Stack HF, Brockman HE: Antimutagenicity profiles for some model compounds. Mutat Res 1990, 238:57-85.

19. Maron DM, Ames BN: Revised methods for the Salmonella mutagenicity test. Mutat Res 1983, 113:173-215.

20. Bernstein L, Kaldor J, Mccann J, Pike MC: An empirical approach to the statistical analysis of mutagenesis data from the Salmonella test. Mutat Res 1982, 97:267-281.

21. Santos FV, Colus IMS, Silva MA, Vilegas W, Varanda EA: Assessment of DNA damage induced by extracts and fractions of Strychnos pseudoquina, a Brazilian medicinal plant with antiulcerogenic activity. Food Chem Toxicol 2006, 44:1585-1589.

22. Loh DS, Er HM, Chen YS: Mutagenic and antimutagenic activities of aqueous and methanol extracts of Euphorbia hirta. J Ethnopharm 2009, 126:406-414.

23. Neigi PS, Jayaprakasha GK, Jena BS: Antioxidant and antimutagenic activities of pomegranate peel extracts. Food Chem 2003, 80:393-397.

24. Resende FA, Munari CC, Monteiro Neto MAB, Tavares DC, Bastos JK, Silva Filho AA, Varanda EA: Comparative studies of the (anti) mutagenicity of Baccharis dracunculifolia and artepillin $C$ by the bacterial reverse mutation test. Molecules 2012, 17:2335-2350.

25. Vargas VM, Mota VE, Henriques JA: Mutagenic activity detected by the Ames test in river water under the influence of petrochemical industries. Mutat Res 1993, 319:31-45.

26. Munari CC, Alves JM, Bastos JK, Tavares DC: Evaluation of the genotoxic and antigenotoxic potential of Baccharis dracunculifolia extract on V79 cells by the comet assay. J Appl Toxicol 2010, 30:22-28.

27. Witte I, Plappert U, de Wall H, Hartmann A: Genetic toxicity assessment: employing the best science for human safety evaluation part III: the comet assay as an alternative to in vitro clastogenicity tests for early drug candidate selection. Toxicol Sci 2007, 97:21-26.

28. Attia SM, Al-Bakheet SA, Al-Rasheed NM: Proanthocyanidins produce significant attenuation of doxorubicin-induced mutagenicity via suppression of oxidative stress. Oxid Med Cell Longev 2010, 3:404-413.

29. Ajith TA, Soja MA: Comparative study on the antimutagenicity of atorvastatin and lovastatin against directly acting mutagens. Cell Biol Toxicol 2006, 22:269-274.

30. Sghaier MB, Boubaker J, Neffati A, Limem I, Skandrani I, Bhouri W, Bouhlel I, Kilani S, Chekir-Ghedira L, Ghedira K: Antimutagenic and antioxidant potentials of Teucrium ramosissimum essential oil. Chem Biodiv 2010, 7:1754-1763.

31. Ajith TA, Janardhanan KK: Antimutagenic effect of Phellinus rimosus (Berk) Pilat against chemical induced mutations of histidine dependent Salmonella typhimurium strains. Food Chem Toxicol 2011, 49:2676-2680.

32. Ross J, Nelson G, Kligerman A, Erexson G, Bryant M, Earley K, Gupta R, Nesnow S: Formation and persistence of novel benzo[a]pyrene adducts in rat lung, liver, and peripheral blood lymphocyte DNA. Cancer Res 1990, 50:5088-5094

33. Chen L, Devanesan PD, Higginbotham S, Ariese F, Jankowiak R, Small GJ, Rogan EG, Cavalieri EL: Expanded analysis of benzo[a]pyrene-DNA adducts formed in vitro and in mouse skin: Their significance in tumor initiation. Chem Res Toxicol 1996, 9:897-903.

34. Chakravarti D, Venugopal D, Mailander PC, Meza JL, Higginbotham S, Cavalieri EL, Rogan EG: The role of polycyclic aromatic hydrocarbon-DNA adducts in inducing mutations in mouse skin. Mutat Res 2008, 649:161-178.

35. Baird WM, Hooven L, Mahadevan B: Carcinogenic polycyclic aromatic hydrocarbon-DNA adducts and mechanism of action. Environ Mol Mutagen 2005, 45:106-114

36. Cao P, Cai J, Gupta RC: Effect of green tea catechins and hydrolyzable tannins on benzo[a]pyrene-induced DNA adducts and structure-activity relationship. Chem Res Toxicol 2010, 23:771-777.

37. Mortelmans K, Zeiger E: The Ames Salmonella/microsome mutagenicity assay. Mutat Res 2000, 455:9-60. 
38. Gursoy-Yuzugullu O, Yuzugullu H, Yilmaz M, Ozturk M: Aflatoxin genotoxicity is associated with a defective DNA damage response bypassing p53 activation. Liver Int 2011, 31:561-571.

39. Wang J, Ogata $M$, Hirai $H$, Kawagishi $H$ : Detoxification of aflatoxin $B_{1}$ by manganese peroxidase from the white-rot fungus Phanerochaete sordida YK-624. FEMS Microbiol Lett 2011, 314:164-169.

40. Zahin M, Aqil F, Ahmad I: Broad spectrum antimutagenic activity of antioxidant active fraction of Punica granatum L. peel extracts. Mutat Res 2010, 703:99-107.

doi:10.1186/1472-6882-12-203

Cite this article as: Resende et al:: Mutagenicity and antimutagenicity of (-)-hinokinin a trypanosomicidal compound measured by Salmonella microsome and comet assays. BMC Complementary and Alternative Medicine 2012 12:203.

\section{Submit your next manuscript to BioMed Central and take full advantage of:}

- Convenient online submission

- Thorough peer review

- No space constraints or color figure charges

- Immediate publication on acceptance

- Inclusion in PubMed, CAS, Scopus and Google Scholar

- Research which is freely available for redistribution 